\title{
Pemanfaatan Ektrak Daun Pepaya (Carica papaya L.) Sebagai Insektisida Nabati Pengendali Walang Sangit (Leptocorisa acuta) Pada Tanaman Padi
}

\author{
Author(s): Nafa Novika Listianti*(1); Wahyu Winarno ${ }^{(1)}$ Iqbal Erdiansyah $^{(1)}$ \\ (1) Jurusan Produksi Pertanian, Politeknik Negeri Jember \\ * Corresponding author: nafanovika@gmail.com
}

\begin{abstract}
ABSTRAK
Keberadaan hama walang sangit (Leptocorisa acuta) sebagai hama utama tanaman padi menyebabkan produksi padi rendah. Pengendalian walang sangit yang biasanya menggunakan insektisida sintetik dinilai kurang efektif karena hama telah resisten terhadap insektisida sintetik. Upaya pengendalian walang sangit dapat dilakukan dengan memanfaatkan bahan yang berasal dari organ tanaman. Penelitian ini bertujuan untuk menekan aktivitas serangan hama walang sangit. Jalan Parangtritis, Kelurahan Antirogo, Kecamatan Sumbersari, Jember merupakan tempat pelaksanaan penelitian. Penelitian ini disusun dengan RAK (Rancangan Acak Kelompok) Non Faktorial, menggunakan tiga perlakuan dan diulang sembilan kali. Perlakuan meliputi P0 (insektisida sintetik bahan aktif deltametrin $1 \mathrm{ml} / \mathrm{L}$ ), P1 (konsentrasi ekstrak daun pepaya 55\%), dan P2 (konsentrasi ekstrak daun pepaya $75 \%$ ). Hasil penelitian menunjukkan bahwa perlakuan P2 (konsentrasi $75 \%$ ekstrak daun pepaya) mampu menekan intensitas serangan walang sangit pada pengamatan minggu ke 3 dan ke 4 dengan rata-rata intensitas serangan 26,31 $\%$ sampai 23,17\%. Selain itu, pada perlakuan P2 (75 \% ekstrak daun pepaya) berpengaruh pada persentase bulir bernas per sampel dengan rerata 38,09\% dan berat padi per sampel dengan rerata $7,11 \mathrm{~g}$.
\end{abstract}

Kata Kunci:

Leptocorisa acuta;

Insektisida

Nabati;

Pepaya;

\begin{tabular}{|c|c|}
\hline & II \\
\hline Keywords: & The presence of stink bug (Leptocorisa acuta) as the main pest of rice causes low rice \\
\hline $\begin{array}{l}\text { Leptocorisa } \\
\text { acuta; }\end{array}$ & $\begin{array}{l}\text { production. Controlling stink bugs that usually use synthetic insecticldes is considered } \\
\text { less effective because pests have been resistant to synthetic insecticides. Efforts to control } \\
\text { the stink bugs can be done by utilizing ingredients derived from plant organs. This study }\end{array}$ \\
\hline & $\begin{array}{l}\text { aims to suppress the attack activity of stink bugs. This study was compiled using non } \\
\text { factorial randomized block design (RBD), three treatments and repeated nine times. The }\end{array}$ \\
\hline $\begin{array}{l}\text { Phyto- } \\
\text { Insecticides;; }\end{array}$ & $\begin{array}{l}\text { treatments include } P 0 \text { (synthetic insecticide deltamethrin } 1 \mathrm{ml} / \mathrm{L}), P 1 \text { (concentration of } \\
\text { papaya leaf extract } 55 \% \text { ), and } P 2 \text { (concentration of papaya leaf extract } 75 \% \text { ). The results } \\
\text { showed that } P 2 \text { treatment (concentration of } 75 \% \text { papaya leaf extract) was able to }\end{array}$ \\
\hline & $\begin{array}{l}\text { suppress the intensity of stink bugs attacks on the observation of } 3 \text { and } 4 \text { weeks with an } \\
\text { average attack intensity of } 26.31 \% \text { to } 23.17 \% \text {. In addition, P } 2 \text { treatment (75\% of papaya } \\
\text { leaf extract) affected the percentage of rice grain per sample with a mean of } 38.09 \% \text { and } \\
\text { weight of rice per sample with a mean of } 7.11 \mathrm{~g} \text {. }\end{array}$ \\
\hline
\end{tabular}




\section{PENDAHULUAN}

Padi (Oryza sativa L) merupakan salah satu tanaman penting di Indonesia karena hasil dari tanaman padi dijadikan sebagai makanan pokok masyarakat Indonesia. Tentunya, dalam produksi padi di Indonesia terkadang mengalami kenaikan dan penurunan disepanjang tahunnya.

Adapun salah satu faktor yang dapat menurunkan produksi padi adalah adanya hama dan penyakit. Kerugian yang dapat mengakibatkan penurunan mutu dan hasil disebabkan oleh hama dan penyakit (Manopo, Salaki, Mamahit, \& Senewe, 2013). Salah satu hama utama tanaman padi yang dapat menurunkan hasil panen hingga $100 \%$ adalah walang sangit. Menurut Yunianti (2016), walang sangit menyerang tanaman padi dengan menusuk bulir padi yang sedang masak susu dan menghisap cairan dalam padi dengan stiletnya yang berakibat bulir padi menjadi hampa atau cacat.

Pengendalian hama walang sangit seringkali menggunakan insektisida sintetik yang dinilai praktis. Pada kenyataanya, pengaplikasian insektisida sintetik berdampak negatif bagi lingkungan sehingga dibutuhkan alternatif lain seperti pestisida nabati yang ramah lingkungan (Nechiyana dkk., 2011).

Salah satu kelebihan dari penggunaan daun pepaya sebagai insektisida nabati adalah mudah didapat, aman terhadap tanaman, sulit menimbulkan kekebalan pada hama. Penelitian yang dilakukan oleh Juliantara (2010), menyatakan bahwa pestisida nabati daun pepaya efektif dalam pengendalian ulat dan hama penghisap. Berdasarkan penelitian yang dilakukan oleh Mawuntu (2015), menunjukkan bahwa pengendalian hama ulat daun pada tanaman kubis dapat dilakukan dengan menggunakan ekstrak daun pepaya sebagai insektisida nabati. Daun pepaya yang baik digunakan sebagai pestisida nabati ialah daun pepaya yang sudah tua karena didalam getah daun pepaya yang sudah tua terdapat lebih banyak kandungan metabolit sekunder papain yang bermanfaat sebagai pengendalian hama.

\section{BAHAN DAN METODE}

Tempat penelitian terletak di Jalan Parangtritis, Kelurahan Antirogo, Kecamatan Sumbersari, Jember. Waktu pelaksanaan penelitian pada bulan November-Maret 2018. Bahan yang digunakan dalam penelitian antara lain daun pepaya, hama walang sangit, malai padi, benih padi, pupuk NPK, pestisida sintetik, dan air.

\section{Rancangan Penelitian}

Rancangan Acak Kelompok (RAK) Non Faktorial dengan 3 perlakuan dengan 9 kali pengulangan pada setiap perlakuan sehingga diperoleh 27 unit percobaan. perlakuan P0 (insektisida sintetik bahan aktif deltametrin), P1 (konsentrasi ekstrak daun pepaya 55\%) dan P2 (konsentrasi ekstrak daun pepaya $75 \%$ ).

\section{Pelaksanaan Penelitian}

Pelaksanaan penelitian ini dimulai dengan uji toksisitas ekstrak daun pepaya terhadap hama walang sangit, kemudian dilanjutkan dengan teknis budidaya tanaman padi yang dimulai dari pengolahan lahan, penanaman, pemeliharaan, pengamatan intensitas serangan hama walang sangit dan pemanenan.

\section{Parameter Pengamatan}

Pengamatan dilakukan dengan menghitung intensitas serangan hama walang sangit dilapang dan menghitung bobot gabah kering sawah per sampel.

\section{Analisis Data}

Data hasil penelitian dianalisis dengan menggunakan ANOVA (Analysis of Variance). Apabila data yang yang 
diperoleh berbeda nyata dilakukan uji lanjut dengan menggunakan uji Duncan's Multiple Range Test (DMRT) dengan taraf $5 \%$.

\section{HASIL DAN PEMBAHASAN Intensitas Serangan Walang Sangit}

Intensitas serangan hama walang sangit ini dilakukan setiap minggu mulai dari awal fase generatif sampai menjelang waktu panen.

Berdasarkan Tabel 1. menjelaskan bahwa semua perlakuan yakni P0 (insektisida bahan aktif deltametrin), P1 (insektisida nabati ekstrak daun pepaya konsentrasi $55 \%$ ) dan P2 (insektisida nabati ekstrak daun pepaya konsentrasi 75 \%) pada pengamatan intensitas serangan 8 dan 9 MST menunjukkan berbeda tidak nyata. Hal ini dikarenakan semua perlakuan (P0, P1, dan P2) tingkat kemanjuran racunnya sama untuk mengendalikan hama walang sangit. Selain itu, alasannya karena pada umur 8 dan 9 MST, bulir padi belum terisi secara merata sehingga ketersediaan makanan untuk walang sangit masih rendah. Pengaplikasian insektisida sintetik dinilai kurang efektif karena hama resisten terhadap insektisida sintetik, sehingga dampak dari penyemprotannya tidak nampak pada intensitas serangan hama.

Tabel 1. Perlakuan Ekstrak Dun Pepaya Terhadap Parameter Intensitas Serangan Hama Walang Sangit (Leptocorisa acuta)

\begin{tabular}{ccccc}
\hline Perlakuan & 8 MST & 9 MST & 10 MST & 11 MST \\
\hline P0 & $30,35 \mathrm{a}$ & $24,79 \mathrm{a}$ & $31,93 \mathrm{a}$ & $30,15 \mathrm{a}$ \\
P1 & $31,78 \mathrm{a}$ & $22,91 \mathrm{a}$ & $27,06 \mathrm{ab}$ & $24,07 \mathrm{ab}$ \\
P2 & $27,03 \mathrm{a}$ & $26,04 \mathrm{a}$ & $26,31 \mathrm{~b}$ & $23,17 \mathrm{~b}$ \\
\hline
\end{tabular}

Keterangan : Angka-angka yang diikuti dengan huruf kecil yang sama memberikan pengaruh yang tidak nyata pada uji DMRT taraf 5\%.

Berdasarkan penelitian yang dilakukan oleh Julaily dan Setyawati (2013), hama dapat resisten jika penyemprotan pestisida dilakukan secara berkala. Selain itu, faktor yang mempengaruhi kurang efektifnya penggunaan insektisida nabati adalah mudahnya pestisida terdegredasi jika terkena sinar matahari (Idris, 2016). Untuk mempertahankan kandungan toksik dalam insektisida nabati sebaiknya diaplikasikan saat pagi atau sore hari.

Sedangkan pada pengamatan intensitas serangan pada 10 dan 11 MST, intensitas serangan walang sangit perlakuan P0 (insektisida bahan aktif deltametrin) menunjukkan tingkat serangan yang melebihi perlakuan P2, dengan konsentrasi $75 \%$ ekstrak daun pepaya. Hal ini menunjukkan bahwa perlakuan P2 ( $75 \%$ ekstrak daun pepaya) efikasi pestisidanya lebih baik dibanding dengan insektisida bahan aktif deltametrin. Penggunaan ekstrak daun pepaya sebagai insektisida nabati ini diduga mampu mengendalikan hama utama tanaman padi yaitu walang sangit dengan cara menghambat proses pencernaan dari hama apabila memakan organ tanaman yang sudah diaplikasian insektisida nabati dari ekstrak daun pepaya. Berdasarkan hasil pengujian yang telah dilakukan oleh Julaily dan Setyawati (2013), menyebutkan getah pepaya mengandung enzim papain, kimopapain, senyawa alkaloid dan flavanoid yang bersifat toksik bagi serangga, sehingga dapat mengendalikan serangga dan organisme pengganggu tanaman. Senyawa papapin yang terkandung dalam daun pepaya berfungsi sebagai racun kontak yang masuk melalui lubang alami pada tubuh serangga dan jika masuk melaui alat mulut serangga dapat bekerja sebagai racun perut. Sehingga akan 
menyebabkan saluran pencernaan rusak dan terganggunya aktivitas makan (Setiawan dan Oka, 2015). Selain itu, senyawa papain dari daun pepaya diduga mampu menghambat aktivitas makan hama dan sebagai racun kontak untuk hama. Menurut Dewi (2010), menyatakan bahwa tinggi rendahnya konsentrasi pestisida yang digunakan akan berpengaruh pada daya kerja racun. Jika konsentrasi yang digunakan tinggi maka pengaruh atau daya kerja racunnya akan semakin tinggi, begitupun sebaliknya.

\section{Bobot Gabah Kering Sawah}

Berdasarkan hasil analisis sidik ragam menunjukkan bahwa bobok gabah kering sawah berpengaruh sangat nyata (high significant) terhadap produksi padi. Sehingga diperlukan uji lanjut menggunakan uji DMRT dengan taraf $5 \%$.

Tabel 2. Berat Per Sampel Padi

\begin{tabular}{cc}
\hline Perlakuan & Rerata Berat Per Sampel \\
\hline P0 & $5,60 \mathrm{a}$ \\
P1 & $6,24 \mathrm{ab}$ \\
P2 & $7,11 \mathrm{~b}$ \\
\hline
\end{tabular}

Keterangan :

Angka-angka yang diikuti dengan huruf kecil yang sama memberikan pengaruh yang tidak nyata pada uji DMRT taraf 5\%.

Berdasarkan Tabel 2. menyatakan bahwa perlakuan P0 (insektisida bahan aktif deltametrin) lebih rendah dibandingkan dengan perlakuan P2 (konsentrasi $75 \%$ ekstrak daun pepaya). Hal ini disebabkan oleh intensitas serangan walang sangit pada perlakuan P2 lebih rendah sehingga bobot gabah kering sawah lebih tinggi (Grafik 1.).

Perlakuan terbaik untuk parameter berat padi per sampel adalah perlakuan P2 (75\%) dengan rata-rata berat per sampel padi adalah 7,11 g. Intensitas serangan hama walang sangit berpengaruh terhadap berat per sampel padi dan produksi padi dalam satuan luas tertentu. Semakin tinggi intensitas serangan pada bulir, semakin tinggi kehilangan hasil padi. Menurut (Zakiyah dan Hoesain (2013), menjelaskan bahwa terdapat keterkaitan antara intensitas serangan walang sangit dengan hasil panen. Hasil panen yang tinggi diakibatkan oleh intensitas serangan walang sangit yang rendah. Dan jika hasil panen rendah diakibatkan oleh intensitas serangan walang sangit yang tinggi.

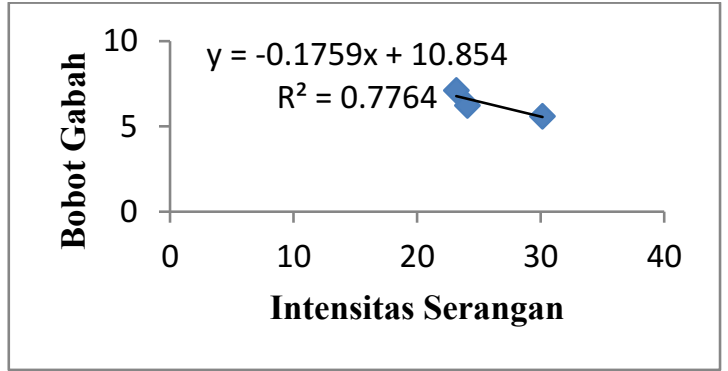

Grafik 1. Hubungan Intensitas Serangan Walang Sangit dengan Bobot Gabah Kering Sawah

\section{KESIMPULAN}

a. Semua perlakuan pada pengamatan intensitas serangan walang sangit 8 MST dan 9 MST tidak berpengaruh terhadap intensitas serangan walang sangit (L. acuta).

b. Perlakuan ekstrak daun pepaya $75 \%$ lebih tinggi dibandingkan dengan pelakuan Deltametrin $\mathrm{ml} / \mathrm{L}$, pada pengamatan intensitas serangan walang sangit 10 MST dan 11 MST memberikan pengaruh terhadap intensitas serangan hama walang sangit (L. acuta) dengan rata-rata $26,31 \%$ dan $23,17 \%$.

c. Perlakuan ektrak daun pepaya $75 \%$ lebih tinggi dibandingkan dengan pelakuan Deltametrin $1 \mathrm{ml} / \mathrm{L}$, memberikan pengaruh terhadap bobot gabah kering sawah per sampel dengan rerata $7,11 \mathrm{~g}$.

\section{DAFTAR PUSTAKA}

Dewi, R. S. (2010). Keefektifan Ekstrak 尌 Tiga Jenis Tumbuhan Terhadap Paracoccus marginatus dan Tetranychus sp. Pada Tanaman Jarak 
Pagar (Jatropha curcas L.) (Thesis, Institiut Pertanian Bogor).

Idris, H. (2016). Formula Insektisida 豇 Nabati Untuk Mengendalikan Hama Penggulung Daun (Pachyzancla stultalis) Pada Tanaman Nilam. Buletin Penelitian Tanaman Rempah Dan Obat, 25(1), 69.

Julaily, N., Mukarlina, \& Setyawati, T. R. 獸 (2013). Pengendalian Hama pada Tanaman Sawi ( Brassica juncea L .) Menggunakan Ekstrak Daun Pepaya ( Carica papaya L .). Jurnal Protobiont, 2(3), 171-175.

Listianti, N. N., Winarno, W., \& Erdiansyah, I. (2019). Pemanfaatan Ektrak Daun Pepaya (Carica papaya L.) Sebagai Insektisida Nabati Pengendali Walang Sangit (Leptocorisa acuta) Pada Tanaman Padi. Agriprima, Journal of Applied Agricultural Sciences, 3(1), 91-100.

Manopo, R., Salaki, C. L., Mamahit, J. E. ., E \& Senewe, E. (2013). Padat Populasi Dan Intensitas Serangan Hama Walang Sangit (Leptocorisa Acuta Thunb.) Pada Tanaman Padi Sawah Di Kabupaten Minahasa Tenggara. COCOS, 2(3).

Mawuntu, M. S. C. (2016). Efektivitas EQ Ekstrak Daun Sirsak Dan Daun Pepaya Dalam Pengendalian Plutella xylostella L. (Lepidoptera; Yponomeutidae) Pada Tanaman Kubis Di Kota Tomohon. Jurnal Ilmiah Sains, 16(1), 24.

Nechiyana, Sutikno, A., \& Salbiah, D. 琶 (2011). Penggunaan Ekstrak Daun Pepaya (Carica papaya L.) Untuk Mengendalikan Hama Kutu Daun (Aphis gossypii Glover) Pada Tanaman Cabai (Capsicum annum
L.) (Universitas Riau).

Setiawan, H., \& Oka, A. A. (2015). EQ Pengaruh Variasi Dosis Larutan Daun Pepaya (Carica papaya L .) Terhadap Mortalitas Hama Kutu Daun (Aphis craccivora ) Pada Tanaman Kacang Panjang ( Vigna sinensis L .) Sebagai Sumber Belajar Biologi. Jurnal Bioedukasi, 6(1), 54-62.

Yunianti, L. (2016). Uji Efektivitas Ekstrak EQ Daun Sirih Hijau (Piper betle) sebagai Insektisida Alami Terhadap Mortalitas Walang Sangit (Leptocorisa acuta) (Skripsi, Universitas Sanata Dharma).

Zakiyah, F., Hoesain, M., \& Wagiyana. 的 (2013). Pemanfaatan Kombinasi Bau Bangkai Kodok dan Insektisida Nabati sebagai Pengendali Hama Walang Sangit ( Leptocorisa acuta T .) Pada Tanaman Padi (Skripsi, Universitas Jember). 